\title{
Effects of Harness Running, Sand Running, Weight - Jacket Running and Weight Training on the Performance of Dribbling and Kicking among the School Going Soccer Players
}

\author{
*Dr. Nazrul Islam Mallick, ** Alauddin Shaikh, *** Dr Ashok Kumar Goon \\ * Lecturer. Deptt. of Physical Education, Hatgobindopur, Burdwan, Dr.B.N.D.S. Mahavidyalaya, W.B, Pin- \\ 713407, India \\ **Asst. Professor,Deptt. of Physical Education, Dr. Meghnad Saha College, Itahar, W.B-India \\ ***Associate Professor \& HOD, Deptt. of Physical Education, Visva-Bharati, Shantineketan-India
}

\begin{abstract}
Background: The purpose of the study was to find the effects of Harness Running, Sand Running, Weight-Jacket Running and Weight training on the performance of Dribbling and kicking among the Burdwan Distrist School going soccer players.

Method-100 male students from the different schools of the Burdwan distrist were randomly selected as subjects and there age were 14-18 years served as Harness Running group (HRG), second group served as Sand Running group (SRG), third group served as Weight-Jacket Running group (WJRG), fourth group served as Weight training group (WTG) and the fifth group served as Control group (CTG).Ten weeks training were given for experiment accordingly. The control group was not given any training except of their routine. The selected subjects were measure of the following soccer skills of Kicking and Dribbling. ANCOVA was calculation for statistical treatment.

Finding: From the finding implies that the Weight Jacket Group was more effective in decreasing the time taken and increasing the distance then all other training programs after ten weeks of training on Dribbling and kicking.

Conclusions: In dribbling Weight Jacket Group showed higher adjusted post-test mean difference with Control Group in comparison to other three training groups which is 0.8 , higher than the critical difference 0.51 required being significant at 0.05 levels.

In kicking Weight Jacket Running Group showed higher adjusted post-test mean difference with Control Group in comparison to other three training groups which are 2.50, higher than the critical difference 1.60 required being significant at 0.05 levels.
\end{abstract}

Keywords: Harness Running, Sand Running, Weight-Jacket Running, Weight training, agility, Dribbling and kicking

\section{Introduction}

Soccer has become a very popular game in the world. Almost all of the nations play the game both for enjoyment and competition. Modern soccer is very fast by its nature. The spectators and the players enjoy the game of soccer with a great amount of merriment. It is a game of constant action and requires continuous adaptation to changing situation by the team as a whole as well as by the individual players although it is a team game, there is ample room for players to display their brilliance through individual performance with the ball as well as through team play involving improvisation and tactical knowledge.

The game of soccer requires considerable amount of physical fitness and mastery in skills. Now the question arises in front of every individual, what do the term physical fitness deals with? Fitness in every specific to the sports or activity which a person does soccer Players must have good endurance, good lower and upper body strength, good flexibility, agility and skill.

The exiting literature in the field of soccer so that endurance, speed, agility, maximum leg strength, upper body strength, leg power, muscular endurance, flexibility, co-ordination and reaction time are important pre requisites for efficient soccer performance.

\section{Methodology}

For the present study the experimental design was adopted on the basis of random group design, and District (Burdwan) School level soccer hundred male students of 14-18 years of age player was selected for this study. Equal numbers of tasks were assigned randomly to five groups of twenty subjects each. The experimental treatments were also assigned randomly for the four experimental groups (A, B, C, D) and control group E. The four experimental groups were administered four different kinds of training programmers for the development of physical fitness and soccer skills. The first group was trained with the method of Harness Running (group-A) 
the second group with the Sand Running (group-B), the third group with Weight - Jacket Running (group-C), the fourth group with Weight - Training (group-D). The distance chosen for each of the training was 80 meters. The training session was conducted thrice a week i.e. on Monday, Wednesday, Friday, for Harness Running and Sand Running Group and Tuesday, Thursday, Saturday for Weight - Jacket Running Group and WeightTraining group. Test programmers were taken before and after an experimental period of 10 weeks. The subjects were advised not to take part in any voluntary sports programmers or unusual physical exhaustion so that physical activities remained uniform for all the groups chosen for the study. The difference between the initial and final scores in shuttle run was subjected to statistical treatment using Analysis of covariance(ANCOVA) to find out whether the mean difference were significant or not. The Scheffe's post hoc test was used to find out the paired means significance difference.

\section{STATISTICAL ANALYSIS}

The following statistical techniques were find out the effects of Harness Running, Sand Running, Weight Jacket Running and Weight training on selected physical fitness component of Dribbling and kicking among the Burdwan Distrist School going soccer players. Analysis of Co-Variance (F ratio) was used to test the adjusted post test mean difference among the experimental groups. The level of significance was set at 0.05 level of confidence.

\section{Result and Discussion \\ Table - 1}

ANALYSIS OF CO-VARIANCE OF FOUR EXPERIMENTAL GROUPS AND CONTROL GROUP ON DRIBBLING

\begin{tabular}{|c|c|c|c|c|c|c|c|c|c|c|}
\hline Mean & $\begin{array}{c}\text { Harness } \\
\text { running } \\
\text { group }\end{array}$ & $\begin{array}{l}\text { Sand } \\
\text { running } \\
\text { group }\end{array}$ & $\begin{array}{c}\text { Weight } \\
\text { jacket } \\
\text { running }\end{array}$ & $\begin{array}{l}\text { Weight } \\
\text { training } \\
\text { group }\end{array}$ & $\begin{array}{c}\text { Control } \\
\text { group }\end{array}$ & \multicolumn{2}{|c|}{$\begin{array}{l}\text { Sum of } \\
\text { square }\end{array}$} & df & $\begin{array}{l}\text { Mean } \\
\text { sum of } \\
\text { square }\end{array}$ & $\begin{array}{c}\text { F- } \\
\text { ratio }\end{array}$ \\
\hline \multirow{2}{*}{ Pre test } & \multirow{2}{*}{20.06} & \multirow{2}{*}{20.95} & \multirow{2}{*}{21.01} & \multirow{2}{*}{21.39} & \multirow{2}{*}{21.14} & A & 20.48 & 4 & 5.12 & \multirow{2}{*}{0.70} \\
\hline & & & & & & $\mathrm{W}$ & 689.95 & 95 & 7.62 & \\
\hline \multirow{2}{*}{ Post test } & \multirow{2}{*}{19.98} & \multirow{2}{*}{20.74} & \multirow{2}{*}{20.39} & \multirow{2}{*}{21.21} & \multirow{2}{*}{21.34} & A & 25.62 & 4 & 6.40 & \multirow{2}{*}{0.86} \\
\hline & & & & & & W & 702.48 & 95 & 7.39 & \\
\hline \multirow{2}{*}{$\begin{array}{l}\text { Adjusted } \\
\text { post test }\end{array}$} & \multirow{2}{*}{20.80} & \multirow{2}{*}{20.60} & \multirow{2}{*}{20.30} & \multirow{2}{*}{20.70} & \multirow{2}{*}{21.10} & A & 6.87 & 4 & 1.71 & \multirow{2}{*}{$2.56^{*}$} \\
\hline & & & & & & W & 62.84 & 94 & 0.66 & \\
\hline
\end{tabular}

*Significant at 0.05 level F.05 $(4,95)=2.46$ F.05 $(4,94)=2.47$

- $\quad \mathrm{N}=100$ (number of subjects)

- $\quad \mathrm{A}=$ Among mean variance

- $\quad \mathrm{W}=$ Within group variance

Table 1 and figure 1 reveals insignificant difference in Dribbling ability among four experimental and one control group Soccer players in pre as well as post-test phases (' $\mathrm{F}$ ' $=0.70$ for the pre-test and 0.86 for post-test means $<2.47$ at $\underline{4}, \underline{95} \mathrm{df}$ ) whereas significant difference is observed in adjusted post-test mean (' $\mathrm{F}$ ' $=2.56>$ 2.47 at $4,95 \mathrm{df}$ ) which was significant at 0.05 level of confidence .

In the case of pre-test mean almost uniform mean values of four experimental groups i.e. Harness Running Group (20.06), Sand Running Group (20.95), Weight Jacket Running Group (21.01), Weight Training Group (21.39) and Control Group (21.14) are found and thereby indicated no significant difference.

In the case of post-test means also except the mean values of Harness Running Group (19.98), Sand Running Group (20.74), Weight Jacket Running Group (20.39), Weight Training Group (21.21) and Control Group (21.34) are found, which also indicate no significant difference among the group.

On other hand in the case of adjusted post-test mean remarkable significant difference in Dribbling mean value among four experimental group and one control group soccer players are noticed, where Control Group mean value (21.1) is found to be highest which is followed by mean value of Harness Running Group (20.80) in comparison to the mean value of Sand Running Group (20.60), Weight Jacket Running Group (20.30) and Weight Training Group (20.70) which was significant at 0.05 level of confidence with the df at $4, \underline{95}$.

As the significance difference in dribbling among four experimental and one control group in adjusted post-test mean are observe. The scheffe's post-hoc-test was computed to find out the existence of significance difference in pair group means, which is presented in table 2 . 
Table - 2

POST HOC MEAN DIFFERENCE COMPARISON OF FOUR EXPERIMENTAL GROUPS AND CONTROL GROUP ON DRIBBLING

\begin{tabular}{|c|c|c|c|c|c|c|}
\hline $\begin{array}{c}\text { Harness } \\
\text { running } \\
\text { group }\end{array}$ & $\begin{array}{c}\text { Sand running } \\
\text { Group }\end{array}$ & $\begin{array}{c}\text { Weight jacket } \\
\text { group }\end{array}$ & $\begin{array}{c}\text { Weight training } \\
\text { group }\end{array}$ & Control group & $\begin{array}{c}\text { Mean } \\
\text { difference }\end{array}$ & $\begin{array}{c}\text { Critical } \\
\text { difference }\end{array}$ \\
\hline 20.80 & 20.60 & & & & 0.2 & 0.51 \\
\hline 20.80 & & 20.30 & & & 0.5 & 0.51 \\
\hline 20.80 & & & 20.70 & & 0.1 & 0.51 \\
\hline 20.80 & & & & 21.10 & 0.3 & 0.51 \\
\hline & 20.60 & 20.30 & & & 0.3 & 0.51 \\
\hline & 20.60 & & 20.70 & & 0.1 & 0.51 \\
\hline & 20.60 & & & 21.10 & 0.5 & 0.51 \\
\hline & & 20.30 & 20.70 & & 0.4 & 0.51 \\
\hline & & 20.30 & & 21.10 & $0.8 *$ & 0.51 \\
\hline & & & & 21.10 & 0.4 & 0.51 \\
\hline
\end{tabular}

*Significant at 0.05 level

Table 2 reveals significant difference in five out of ten paired group means.

The paired group means, which showed significant difference between Weight Jacket Running Group and Control Group $(0.8>0.51)$ at 0.05 level of confidence.

No significant difference between paired group mean namely between Harness Running Group and Sand Running Group $(0.2<0.51)$ between Harness Running Group and Weight Jacket Running Group $(0.5<$ $0.51)$ between Harness Running Group and Weight Training Group $(0.1<0.51)$ between Harness Running Group and Control Group $(0.3<0.51)$ between Sand Running Group and Weight Jacket Running Group $(0.3<$ $0.51)$ between Sand Running Group and Weight Training Group $(0.1<0.51)$ between Sand Running Group and Control Group $(0.5<0.51)$ between Weight Jacket Running Group and Weight Training Group $(0.4<0.51)$ between Weight Training Group and Control Group $(0.4<0.51)$ are observed.

The Graphical representation of mean comparison of dribbling for four experimental group and one control group after ten weeks of experimental programmed is presented in figure -1 .

\section{MEAN COMPARISON OF FOUR EXPERIMENTAL GROUPS AND CONTROL GROUP ON DRIBBLING}

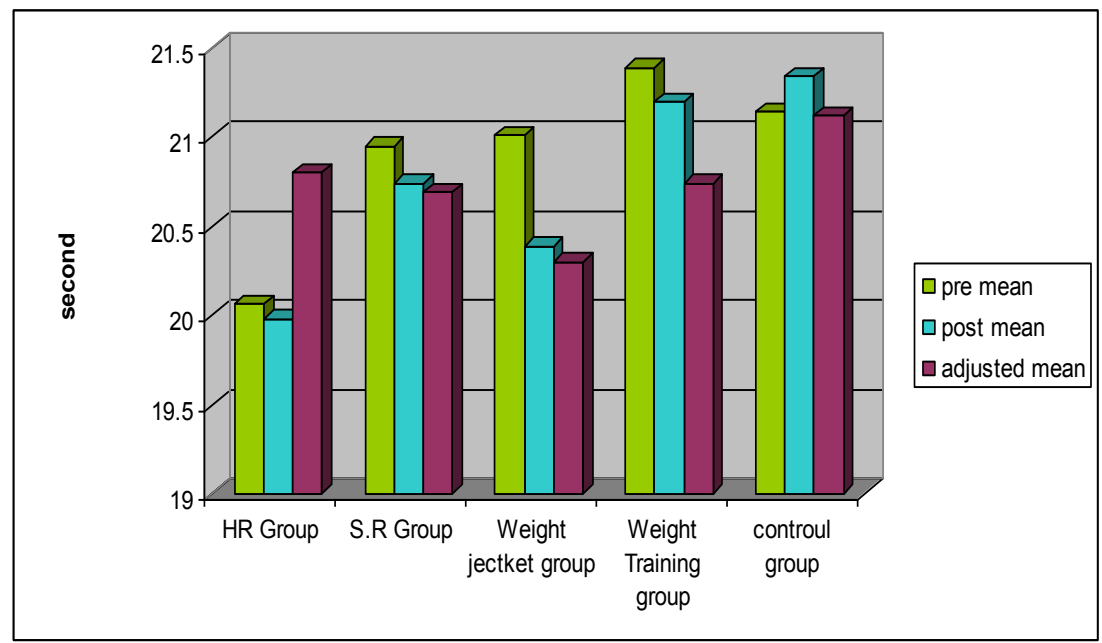

Figure- 1

Here it is clearly observed that the highest dribbling time was taken by Weight Training Group in pre-test data followed by Control Group, Weight-Jacket Running Group, Sand Running Group and Harness Running Group respectively. The highest dribbling time was taken by Control Group in post-test data followed by Weight Training Group, Sand Running Group, Weight Jacket Running Group and Harness Running Group respectively. The lowest adjusted mean value was found in Weight Jacket Running Group followed by Sand Running Group, Weight Training Group, Harness Running Group and Control Group respectively.

The finding implies that Weight Jacket Group was more effective in decreasing the time taken 
then all other training programs after ten weeks of training on dribbling.

Table - 3

ANALYSIS OF CO-VARIANCE OF FOUR EXPERIMENTAL GROUPS AND CONTROL GROUP ON KICKING

\begin{tabular}{|c|c|c|c|c|c|c|c|c|c|c|}
\hline Mean & $\begin{array}{c}\text { Harness } \\
\text { running } \\
\text { group }\end{array}$ & $\begin{array}{c}\text { Sand } \\
\text { running } \\
\text { Group }\end{array}$ & $\begin{array}{l}\text { Weight } \\
\text { jacket } \\
\text { running } \\
\text { group }\end{array}$ & $\begin{array}{c}\text { Weight } \\
\text { training } \\
\text { group }\end{array}$ & $\begin{array}{c}\text { Control } \\
\text { group }\end{array}$ & \multicolumn{2}{|c|}{$\begin{array}{l}\text { Sum of } \\
\text { square }\end{array}$} & Df & $\begin{array}{c}\text { Mean } \\
\text { sum of } \\
\text { square }\end{array}$ & $\begin{array}{c}\text { F- } \\
\text { ratio }\end{array}$ \\
\hline \multirow{2}{*}{$\begin{array}{l}\text { Pre } \\
\text { test }\end{array}$} & \multirow{2}{*}{24.20} & \multirow{2}{*}{24.90} & \multirow{2}{*}{26.25} & \multirow{2}{*}{24.85} & \multirow{2}{*}{22.15} & A & $\begin{array}{c}179.6 \\
0\end{array}$ & 4 & 44.76 & \multirow{2}{*}{0.94} \\
\hline & & & & & & W & $\begin{array}{c}4493 . \\
8\end{array}$ & 95 & 47.30 & \\
\hline \multirow[b]{2}{*}{$\begin{array}{c}\text { Post } \\
\text { test }\end{array}$} & \multirow[b]{2}{*}{25.25} & \multirow[b]{2}{*}{25.90} & \multirow[b]{2}{*}{28.30} & \multirow[b]{2}{*}{26.40} & \multirow[b]{2}{*}{21.90} & $\mathrm{~A}$ & 436.4 & 4 & 109.1 & \multirow[b]{2}{*}{2.22} \\
\hline & & & & & & W & $\begin{array}{c}4658 . \\
3\end{array}$ & 95 & 49.03 & \\
\hline \multirow{2}{*}{$\begin{array}{c}\text { Adjus } \\
\text { ted } \\
\text { post } \\
\text { test }\end{array}$} & \multirow[b]{2}{*}{25.50} & \multirow[b]{2}{*}{25.49} & \multirow[b]{2}{*}{26.60} & \multirow[b]{2}{*}{26.03} & \multirow[b]{2}{*}{24.10} & $\mathrm{~A}$ & 66.69 & 4 & 16.67 & \multirow[b]{2}{*}{$\begin{array}{c}2.58 \\
*\end{array}$} \\
\hline & & & & & & W & 605.2 & 94 & 6.43 & \\
\hline
\end{tabular}

*Significant at 0.05 level F.05 $(4,95)=2.46$ F.05 $(4,94)=2.47$

$\mathrm{N}=100$ (number of subjects)

$\mathrm{A}=$ among mean variance

$\mathrm{W}=$ within group variance

Table 3 and figure 2 reveals insignificant difference in Kicking ability among four experimental and one control group Soccer players in pre as well as post-test phases ( $\mathrm{F}$ ' $=0.94$ for the pre-test and 2.22 for post-test means $<$ 2.47 at $\underline{4}, \underline{95} \mathrm{df}$ ) whereas significant difference is observed in adjusted post-test mean (' $\mathrm{F}$ ' $=2.58>2.47$ at $\underline{4}, \underline{95}$ df) which were significant at 0.05 level of confidence .

In the case of pre-test mean almost uniform mean values of four experimental groups i.e. Harness Running Group (24.20), Sand Running Group (24.90), Weight Jacket Running Group (26.25), Weight Training Group (24.85) and Control Group (22.15) are found and thereby indicated no significant difference.

In the case of post-test means also except the mean values of Harness Running Group (25.25), Sand Running Group (25.90), Weight Jacket Running Group (28.30), Weight Training Group (26.40) and Control Group (21.90) are found, which also indicate no significant difference among the group.

On other hand in the case of adjusted post-test mean remarkable significant difference in Kicking mean value among four experimental group and one control group soccer players are noticed, where Weight Jacket Group mean value (26.60) is found to be highest which is followed by mean value of Weight Training Group (26.03) in comparison to the mean value of Harness Running Group (25.50), Sand Running Group (25.49) and Control Group (24.10) which were significant at 0.05 level of confidence with the df at $\underline{4}, \underline{95}$.

As the significance difference in physical fitness among four experimental and one control group in adjusted post-test mean are observe. The scheffe's post-hoc-test was computed to find out the existence of significance difference in pair group means, which is presented in table 4 .

Table - 4

POST HOC MEAN DIFFERENCE COMPARISON OF FOUR EXPERIMENTAL GROUPS AND CONTROL GROUP ON KICKING

\begin{tabular}{|c|c|c|c|c|c|c|}
\hline $\begin{array}{c}\text { Harness running } \\
\text { group }\end{array}$ & $\begin{array}{c}\text { Sand running } \\
\text { group }\end{array}$ & $\begin{array}{c}\text { Weight jacket } \\
\text { group }\end{array}$ & $\begin{array}{c}\text { Weight } \\
\text { training } \\
\text { group }\end{array}$ & $\begin{array}{c}\text { Control } \\
\text { group }\end{array}$ & $\begin{array}{c}\text { Mean } \\
\text { difference }\end{array}$ & $\begin{array}{c}\text { Critical } \\
\text { difference }\end{array}$ \\
\hline 25.50 & 25.49 & & & & 0.01 & 1.60 \\
\hline 25.50 & & 26.60 & & & 0.1 & 1.60 \\
\hline 25.50 & & & 26.03 & & 0.53 & 1.60 \\
\hline 25.50 & & & 24.10 & 1.4 & 1.60 \\
\hline & 25.49 & 26.60 & & & 1.11 & 1.60 \\
\hline & 25.49 & & 26.03 & & 0.54 & 1.60 \\
\hline & 25.49 & & & 24.10 & 1.39 & 1.60 \\
\hline & & 26.60 & 26.03 & & 0.57 & 1.60 \\
\hline & & 26.60 & & 24.10 & $2.5^{*}$ & 1.60 \\
\hline
\end{tabular}

*Significant at 0.05 level 
Table 4 reveals significant difference in five out of ten paired group means.

The paired group means, which showed significant difference between Weight Jacket Running Group and Control Group $(2.5>1.60)$ between Weight Training Group and Control Group $(1.93>1.60)$ at 0.05 level of confidence.

No significant difference between paired group mean namely between Harness Running Group and Sand Running Group $(0.01<1.60)$ between Harness Running Group and Weight Jacket Running Group $(0.1<$ 1.60) between Harness Running Group and Weight Training Group $(0.53<1.60)$ between Harness Running Group and Control Group $(1.4<1.60)$ between Sand Running Group and Weight Jacket Running Group $(1.11<$ $1.60)$ between Sand Running Group and Weight Training Group $(0.54<1.60)$ between Sand Running Group and Control Group $(1.39<1.60)$ between Weight Jacket Running Group and Weight Training Group $(0.57<$ 1.60) are observed.

The Graphical representation of mean comparison of kicking for four experimental group and one control group after ten weeks of experimental programmed is presented in figure -2 .

\section{MEAN COMPARISON OF FOUR EXPERIMENTAL GROUPS AND CONTROL GROUP ON KICKING}

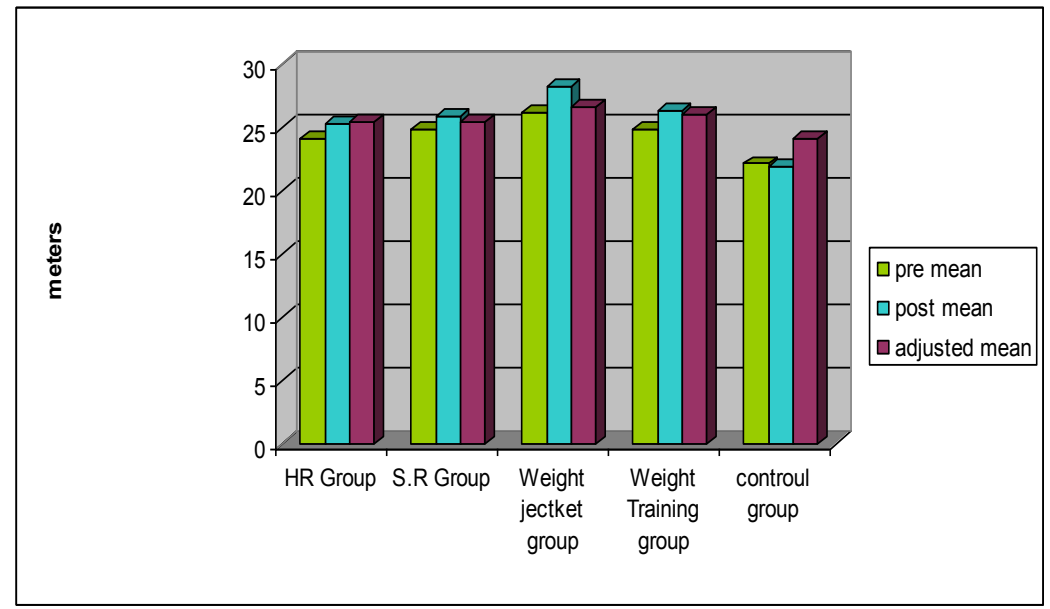

Figure- 2

In kicking for distance it is clearly observe that the longest distance was covered by Weight Jacket Running Group in pre-test data followed by Sand Running Group, Weight Training Group, Harness Running Group and Control Group respectively. In the post-test data the longest distance was covered by Weight Jacket Running Group followed by Weight Training Group, Sand Running Group, Harness Running Group and Control Group respectively. The highest adjusted mean value was found in Weight Jacket Running Group followed by Weight Training Group, Harness Running Group, Sand Running Group and Control Group respectively.

The finding implies that Weight Jacket Group was more effective in increasing the distance then all other training programs after ten weeks of training on kicking.

\section{Conclusions}

The results of this study, the following conclusions were drawn.

1. Weight-jacket group produce best performance in dribbling.

2. Weight-Jacket group was executed significantly better Performance in kicking than that of other three groups.

10. No improvement in the case of control group which was a reflection of inactivity.

(BOOKS)

\section{Reference}

[1]. Beim, George. Principles of Modern Soccer. London : Houghton Mifflin Company, 1977.

[2]. Baver, Gerhard. How to succeed at soccer. London :Orbis Publishing, 1982.

[3]. Moris, Desmond. Soccer Tribe .London: Jonathan Cap Ltd., 30 Bedford Square, 1981.

(JOURNAL AND PERIODICALS)

[4]. Capen, Edward K. "The Effect of Systematic weight Training on Power,Strength and Endurance" Research Quarterly 21 (May 1950): 83 .

[5]. Cassel, Allen A Grassy. "A comparison of Motor Abilities and physical Characteristics of Collegiate Soccer Player by Position of play” Dissertation Abstract International 39:8 (February 1979): 4805- A. 
[6]. Hess, Robert C. "The Effect of Weight Training Programe on Soccer Kicking for Distance" Completed Research in Health, Physical Education and Recreation 8 (1966): 97.

[7]. Boyer, Robert A. "A study of determine the effect of weight training in the development in soccer" Completed Research in Health, Physical Education and Recreation 6 (1964) : 89.

[8]. Sharma, P.D. "The Role of Mass Media in Promotion of Sports and Physical Education in India" Journal of Physical Education 2:1 (May 1986) : 1

\section{(UNPUBLISHED THESIS)}

[9]. Bandopadhyay, Subhas Chandra. "Relationship of Selected

[10]. Anthropometric Physical Fitness and Motor Abilities to Soccer Skill Performance" Unpublished Masters Thesis, Jiwaji University. April, 1982.

[11]. Shagi, P. "performance variations in selected soccer skills on different ground condition" Unpublished Master Degree thesis, LsNUPE. Gwalior. 1996. 